\title{
The Influence of Capital Structure and Dividends Policy to Firms Value Listed at Indonesian Stock Exchange
}

\author{
Linna Ismawati \\ Program Studi Manajemen \\ Universitas Komputer Indonesia \\ Bandung, Indonesia \\ linna.ismawati@email.unikom.ac.id
}

\begin{abstract}
This research aims to find evidence on whether the capital structure and dividend's policy have an impact on the firm's value. The study uses a firm-level panel data as all companies listed at Indonesian Stock Exchange who pays the dividend during the period of 2010-2015. The study develops three reseach hypoteses, which are used to represent the main theories of capital structure and theories of corporate dividends. The method used in this research consisted of the quantitative research method using explanatory survey. The design of analysis used is multiple regression analysis, coefficient of correlation analysis, and coefficient of determinant analysis. While hypothesis testing using t-test and $F$ test. The research finding shows in partial effect the capital structure had the impact on firm's value, but the dividend's policy had not impacted significantly on firm's value. In simultaneously effect the capital structure and dividend's policy had the impact to firm's value. The implication of this study is to provide input for managers in establishing capital structure policies and dividend policies to increase the value of the company.
\end{abstract}

Keywords: Capital Structure, Dividends Policy, Firms Value.

\section{I.INTRODUCTION}

Amidu's study found that dividend payout ratio, capital structure (leverage), company growth has a positive effect on firm value [1]. Research on the effect of financial performance in this case Capital Structure on the value of the company shows inconsistent results.

Ulupui states that the firm's value is determined by earnings power from the company's assets. Positive results show that the higher earnings power, the more efficient the asset turnover and / or the higher dividend obtained by the company [2]. This has an impact on increasing the value of the company. Research conducted by Ulupui found the results that dividend has a significant positive effect on stock returns in the next period. Therefore, dividend is one of the factors that influence the value of the company. The difference in the results of this study shows that there are other factors that also influence the ROE relationship with the company's value.

Modigliani and Miller in DeAngelo et al. stated that on the irrelevance of dividends, a number of theories have been put forward for a perfect capital market. One important theory that has been widely researched in the literature and has received supporting evidence is agency theory.
[3]According to Jensen agency theory, dividend policy is determined by agency costs arising from ownership and control divergences. Because of agency costs, managers may not always adopt dividend policies that maximize shareholder values. Instead, they might choose dividend policies that maximize their own personal benefits. [4]

The empirical relationship between dividends and market values in the corporate valuation model developed by Olsen (1989) has been at the forefront of financial research over the past decade[5]. Ross, found that dividends have a positive influence on company valuations in the UK[6].

Giner and Rees in Ross, found that for the United States and Spain. The positive impact of dividends on company valuations can be attributed to the fact that managers' information signals about future profitability[6]. A typical econometric approach for the study above is to use observation samples taken from many companies over a period of time, with estimates based on OLS techniques (where all years are considered identical). An implicit assumption made in this methodology is that the explanation of variables in the company's valuation model follows a stationary process.

Research by Miller and Rock, proposed that adjusting the signal of changes in future dividends in the future cash flows expected by the company, and in the value of the company. A number of studies have attempted to measure market response to changes in dividends [7].

This research was conducted on manufacturing companies in Indonesia during the 2006-2015 periods. Research on capital structure determinants and dividend policy rests on reasons related to deregulation of a number of regulations in Indonesia. Changes to the funding pattern before deregulation was rolled out, many company funding was carried out by financial market institutions dominated by banks as creditors. Currently, after the government deregulation related to capital market funding, it provides opportunities for companies to obtain funding from the capital market through the issuance of shares and bonds. Of course, it is followed by the company's obligation to prosper shareholders and fulfill obligations to investors in accordance with the No. 40 of 2007 Law concerning the company. 
The company's dividend policy in Indonesia, both stateowned and private, is a complex problem and has major financial implications. How much dividend needs to be given to shareholders and how much for reinvestment is an interesting thing to study. Based on Law No. 40 of 2007 concerning Article 72 of Limited Liability Companies, dividend distribution is made based on the Annual General Meeting of Shareholders (AGMS) or Extraordinary General Meeting of Shareholders (EGM). Before the end of the financial year dividends can be distributed as long as they do not reduce the company's net assets. This deregulation is often not fulfilled by many companies in Indonesia because the board of directors is given the authority to change the dividend policy from time to time even though they still pay attention to the AGM approval, operational and financial, financial condition, liquidity, business prospects, and compliance with applicable laws and regulations. The absence of a minimum limit for dividend distribution to shareholders, often results in companies not paying dividends.

The originality of this research is the use of a more comprehensive capital structure determinant variable and dividend policy then the next stage to analyze simultaneously the capital structure variables and their implications for firm value. This research was carried out based on the empirical gap phenomenon and the theoretical gap described above and there has not been much research on companies in Indonesia that combine determinants of capital structure and dividend policies that influence the increase in firm value. This study contributes to managers to make informed decisions in the capital structure policy and dividend policy so that it has an impact on increasing the value of the company.

Tracing the previous researches and looking at empirical conditions in the company, there are differences in research results that lead to academic debates or inconsistencies in the results of previous studies that examine the determinants of capital structure and dividend policy on firm value. This condition motivates the author to carry out more comprehensive advanced research on this topic.

The main issue of this research is about capital structure and dividend policy with company value, which is testing the effect of capital structure and dividend policy on company value. Research on factors that influence the value of the company has been carried out.

\section{II.METHOD}

The research method used in this study is a verification method with a quantitative approach. Quantitative method is used to examine the effect of capital structure variables and dividend policy on increasing the value of the company. The sample in this study is capital structure, Dividend payout ratio, and Tobins'q ratio report on 36 manufacturing companies. The design of quantitative analysis is multiple regression analysis, correlation coefficient analysis, determination coefficient analysis and hypothesis testing. Partial hypothesis testing using T test and hypothesis testing simultaneously through the $\mathrm{F}$ test. operatinalization of variable can be seen in table 1
TABLE I. OPERATIONALIZATION OF VARIABLES

\begin{tabular}{|c|c|c|c|c|}
\hline $\begin{array}{l}\text { Varia } \\
\text { ble }\end{array}$ & $\begin{array}{c}\text { Varia } \\
\text { ble } \\
\text { Conce } \\
\text { pts }\end{array}$ & $\begin{array}{c}\text { Indicato } \\
\text { rs }\end{array}$ & Size & Scale \\
\hline \multicolumn{5}{|c|}{ Endogeneous Variables (Dependent Variables) } \\
\hline $\begin{array}{l}\text { Firm } \\
\text { Values }\end{array}$ & $\begin{array}{l}\text { A } \\
\text { concep } \\
\text { t that } \\
\text { shows } \\
\text { current } \\
\text { financi } \\
\text { al } \\
\text { market } \\
\text { estimat } \\
\text { es of } \\
\text { returns } \\
\text { from } \\
\text { each } \\
\text { increm } \\
\text { ental } \\
\text { invest } \\
\text { ment. }\end{array}$ & $\begin{array}{l}\text { MVE = } \\
\text { Market } \\
\text { Value of } \\
\text { Equity } \\
\text { DEBT = } \\
\text { (Current } \\
\text { Liabilitie } \\
\text { s-Current } \\
\text { Asset)+i } \\
\text { nventory } \\
\text { + Non } \\
\text { Current } \\
\text { liabilities }\end{array}$ & 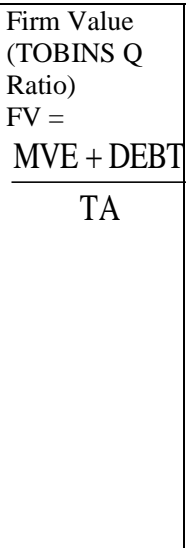 & $\begin{array}{l}\text { Quantitativ } \\
\mathrm{e} \\
\text { Ratio }\end{array}$ \\
\hline \multicolumn{5}{|c|}{ Exogenous variables (Independent Variables) } \\
\hline $\begin{array}{l}\text { Capital } \\
\text { Structu } \\
\text { re }\end{array}$ & $\begin{array}{l}\text { The } \\
\text { amoun } \\
\text { t of the } \\
\text { total } \\
\text { liabilit } \\
y \text { is } \\
\text { compa } \\
\text { red } \\
\text { with } \\
\text { the } \\
\text { capital } \\
\text { itself } \\
\text { (Total } \\
\text { Debt to } \\
\text { Equity } \\
\text { ) }\end{array}$ & $\begin{array}{l}\text { DEBT = } \\
\text { Total } \\
\text { debt } \\
\text { EQUITY } \\
=\text { Total } \\
\text { equity }\end{array}$ & $\begin{array}{l}\text { Debt to } \\
\text { Equity Ratio } \\
\text { DER }= \\
\frac{\text { Debt }}{\text { Equity }}\end{array}$ & $\begin{array}{l}\text { Quantitativ } \\
\mathrm{e} \\
\text { Ratio }\end{array}$ \\
\hline $\begin{array}{l}\text { Divide } \\
\text { nd } \\
\text { Policy }\end{array}$ & $\begin{array}{l}\text { Is a } \\
\text { part of } \\
\text { profit } \\
\text { or a } \\
\text { measur } \\
\text { e of } \\
\text { the } \\
\text { proport } \\
\text { ion of } \\
\text { the } \\
\text { compa } \\
\text { ny's } \\
\text { profit } \\
\text { that is } \\
\text { distrib } \\
\text { uted to } \\
\text { shareh } \\
\text { olders. }\end{array}$ & $\begin{array}{l}\text { DPS = } \\
\text { Dividend } \\
\text { Per Share } \\
\text { EPS = } \\
\text { Earning } \\
\text { Per Share }\end{array}$ & $\begin{array}{l}\text { Dividend } \\
\text { Payout Ratio } \\
=\mathrm{DPR} \\
\mathrm{DPR}= \\
\text { DPS } \\
\text { EPS }\end{array}$ & $\begin{array}{l}\text { Quantitativ } \\
\mathrm{e} \\
\text { Ratio }\end{array}$ \\
\hline
\end{tabular}

Research Hypothesis

$\mathrm{H}_{1}$ : Capital structure affects the value of the company $\mathrm{H}_{2}$ : Dividend policy affects the value of the company $\mathrm{H}_{3}$ : Capital Structure and Dividend Policy simultaneously affect the value of the company.

\section{III.RESULT}

To prove that the model of the influence of capital structure determinants and dividend policy on firm value, a 
series of tests is performed by looking at the coefficient of variation (R2) and F test. The empirical model of the estimation results of firm value models on companies listed on the Stock Exchange can be seen in table 2 below.

TABLE II. RESULTS OF TESTING THE CAPITAL STRUCTURE HYPOTHESIS AND DIVIDEND POLICY AGAINST COMPANY VALUES

\begin{tabular}{|c|c|c|c|c|c|}
\hline $\begin{array}{l}\text { Independ } \\
\text { ent } \\
\text { Variables }\end{array}$ & $\begin{array}{c}\text { Expect } \\
\text { ed } \\
\text { Sign }\end{array}$ & $\begin{array}{c}\text { Coeffici } \\
\text { ent }\end{array}$ & $\begin{array}{c}\text { t_statist } \\
\text { ics }\end{array}$ & Prob & $\begin{array}{c}\text { Conclusio } \\
\mathbf{n}\end{array}$ \\
\hline$C$ & & 6,5851 & 1.87645 & 0,0000 & $\begin{array}{c}\text { Ho } \\
\text { rejected } \\
\text { the } \\
\text { sign. on } \\
\alpha=0.1\end{array}$ \\
\hline $\begin{array}{c}\text { Capital } \\
\text { Structure } \\
\text { (DER) }\end{array}$ & $(+) /(-)$ & 0,0476 & 4.3428 & $\begin{array}{c}0,0089 \\
* *\end{array}$ & $\begin{array}{c}\text { Ho } \\
\text { rejected } \\
\text { the } \\
\text { sign. on } \\
\alpha=0.05\end{array}$ \\
\hline $\begin{array}{l}\text { Dividend } \\
\text { Policy } \\
\text { (DPR) }\end{array}$ & $(+) /(-)$ & 0.0263 & 3.4689 & $\begin{array}{l}0.0672 \\
*\end{array}$ & $\begin{array}{c}\text { Ho } \\
\text { rejected } \\
\text { the } \\
\text { sign. on } \\
\alpha=0.10\end{array}$ \\
\hline $\begin{array}{c}F \text {-stat } \\
\text { Adjusted } \\
R^{2}\end{array}$ & $(+)$ & $\begin{array}{c}124,867 \\
2 \\
0.6153\end{array}$ & & 0.0000 & $\begin{array}{c}\text { Ho } \\
\text { rejected } \\
\text { the } \\
\text { sign. on } \\
\alpha=0.05\end{array}$ \\
\hline
\end{tabular}

Based on the equation 3 model in Table 2, the adjusted value of $\mathrm{R}^{2}$ is 0.6153 which means that 61.53 percent of the changes in the endogenous variable (firm value) can be explained by exogenous variables consisting of capital structure (DER) and dividend policy (DPR). With the results of F-stat 124.8672 probability value of 0.0000 , it can be concluded that the exogenous variables contained in the model can describe linear relationships with endogenous variables or in other words the capital structure and dividend policy together have a significant effect on firm values.

\section{IV.DISCUSSION}

To prove that the model of the influence of capital structure determinants and dividend policy on firm value is carried out a series of tests by looking at the coefficient of variation $\left(\mathrm{R}^{2}\right)$ and $\mathrm{t}$ test. Based on the $\mathrm{t}$ _statistic test results, The capital structure in table 2 shows the t_statistic value of -4.34280. This t_statistic value is greater than the value of t_table of $2.01367(4.34280>2.01367)$, at the $5 \%$ significance level so that the $\mathrm{H}_{0}$ Hypothesis is rejected, which means that the capital structure has a significant effect on firm value. The regression coefficient for capital structure variable (DER) is 0.0476 with the acquisition of a probability value of 0.0089 with a $95 \%$ confidence level there is a strong reason to conclude that the capital structure has a positive and significant effect on firm value. Value of capital structure tends to affect stock prices in the capital market. Developing companies usually increase the amount of debt for expansion. When the capital structure is low, it means that the company uses more internal funds so that the Cost of Capital is relatively small compared to the costs for external funding. However, this condition cannot necessarily increase the company's growth. Therefore, for growth, companies usually add external funding from debt to obtain a much greater profit. Thus, investors will get an increase in welfare. The results of this study are in accordance with the results of Kartika et al [8] and Purwanto [9] research which states that the capital structure is used in the framework of expansion by increasing external funding. Thus, investors will get an increase in welfare. When a company adds its debt, it means that the company is developing and the opportunity to get a relatively large profit is a positive information for investors to invest their funds in the company and this will obviously increase the value of the company.

The test results show the beta coefficient value of the capital structure proved to have a significant effect on firm value. The results of this study are in accordance with previous estimates and are appropriate and supportive of Stephen A. Ross (1977) with signaling theory [6]. The results of the study do not support the results of previous studies, namely Ardi et al (2016), which concluded that capital structure variables have a significant negative effect on stock prices[10]. If the company's capital structure is low in the sense that the value of the debt is smaller than its own capital, there will be an increase in the share price, automatically raising the value of the company.

The results of this study provide an empirical understanding for management that if the company's performance is good, then the value of the company also rises. This condition shows that the increase in the company's performance is captured directly as a positive signal for investors, so that the stock price rises, the increase in the amount of external funds shows the success of the company in implementing its policy. This success drives the company's stock price to rise, because the stock market practitioners will get a high return from their investment.

This result is in line with the results of ModiglianiMiller's study in 1961 which states that an optimal capital structure will increase firm value. The results of this study are also in accordance with the previous research conducted by Purwanto which presents the results of research that the factors of capital structure affect the change in firm value. Changes in capital structure factors will encourage the achievement of optimal corporate value [9].

To prove that the model of the influence of dividend policy on company value is carried out a series of tests by looking at the coefficient of variation $\left(\mathrm{R}^{2}\right)$ and $\mathrm{t}$ test. The empirical model of the estimation of the company's value model in companies listed on the Stock Exchange can be seen in table 4.13 above.

Based on the t_statistic test results, the dividend policy shows the t_statistic value of 0.46892 . This $t$ _statistic value is smaller than the value of $t$ table of 2.579 (3.4689 <2.579 ), at a significance level of $10 \%$ so that the $\mathrm{H}_{0}$ Hypothesis is rejected, which means the dividend policy (Dividend Payout Ratio) has a significant effect on Firm Value.

The regression coefficient for dividend variable (DPR) is 0.0263 and the probability value is 0.0672 with a $90 \%$ confidence level. It can be concluded that the DPR has a 
significant positive effect on the value of the company. Dividends are not the only factor that is considered by shareholders in investing, especially because the dividend value received by investors is relatively small. Investors actually expect profits or returns from capital gains. The results of this study explain that the value of the company is largely determined by its basic ability to generate profits and business risks. In other words, the value of the company depends solely on the income generated by its assets, not on how the income is divided between dividends and retained earnings. This result is not in line with the results of De Angelo et al., which states that dividends do not increase firm value [3]. The same research was carried out by companies in Indonesia by Kartika et al stating that there was no positive effect on firm value [8]. This shows that, distributing dividends in a row that is in accordance with the method of selecting research samples is not always a positive signal for investors. This arises because investors assume that company managers are less sensitive to investment opportunities that can generate profits. The test results of this hypothesis show that the effect of dividend payout ratio on firm value has a positive but insignificant direction of the coefficient. This is in line with the theory put forward by Miller and Modigliani who argued that dividend policy does not affect the value of the company because according to them the ratio of dividend payments are only the details and does not affect the welfare of shareholders.

Based on the results of testing the hypothesis, it can be explained that the findings of this study are rejecting theory as a theory of dividend relevance from Amidu's findings on the Ghana Stock Exchange [1].

\section{V.CONCLUSION}

Capital structure affects the value of the company. The results of this study support the Signaling theory where companies that are experiencing rapid growth certainly become positive information for investors in investing. Companies that are experiencing growth are always being hunted by investors to invest their funds in the company so that ultimately the stock price increases and the value of the company will automatically increase. On the other hand, dividend policy with a relatively small value does not have a large impact on increasing the value of the company. The amount of dividends paid with a small value can no longer give a positive signal about the actual condition of the company so the dividend policy becomes less informative. Therefore, changes in dividend policy significantly influence changes in company value.

\section{ACKNOWLEDGMENT}

The author would like to thank the UN Chancellor Dr. Ir. H. Eddy Soeryanto Soegoto., And Dean of the Faculty of Economics and Business Prof. Dr. Hj. Dwi Kartini Yahya., SE., Spec. Lic, who has given the opportunity to conduct this research.

\section{REFERENCES}

[1]. Amidu, Mohammed, \& Joshua Abor, 2007, Determinants of Dividend Payout Ratios in Ghana, The Joumal of Risk Finance 7(2), 136-145

[2]. Ulupui, I. G. K. A, 2007, Analisis Pengaruh Rasio Likuiditas, Leverage, Aktivitas, dan Profitabilitas terhadap Return Saham, Jurnal Akuntansi dan Bisnis Vol.2. 25-28

[3]. DeAngelo, H. and R. Masulis, 1996, Optimal Capital Stucture Under Corporate and Personal Taxation, Journal of Financial Economics 8, 3-29

[4]. Jensen, M., 1986, Agency Costs of Free Cash Flo, Corporate Finance, and Takeovers, American Economic Review 76, 323 329.

[5]. Olsen, R. A. 1998. "Behavioral finance and its implications for stock-price volatility”. Financial Analysis Journal 54, 118-124.

[6]. Ross, S. A., 1977, The Determination of Financial Structure: The Incentive Signaling Approach, Bell Journal of Economics 8, 23-40.

[7]. Miller, M. and . D. Modigliani 1961, Dividend Policy, Growth, and the Valuation of Shares, Journal of Business 34, 411-433.

[8]. Kartika Chandra, Fachrudin, Isfenti Sadalia, \& Rikson Siburian.2017. The Effect of Capital Structure, Profitability and Dividend Policy on Intrinsic Value of Firm. Research Journal of Finance and Accounting. 101-107

[9]. Purwanto Handoko. 2017. The Influence of Firm's Size, Growth, and Profitability on Firm Value with Capital Structure as the Mediator: A Study on the Agricultural Firms Listed in the Indonesian Stock Exchange. International Journal of Economics and Finance. 103-110

[10]. Ardi Paminto Djoko Setyadi Jhonny Sinaga. 2016. The Effect of Capital Structure, Firm Growth and Dividend Policy on Profitability and Firm Valueof the Oil Palm Plantation Companies in Indonesia. European Journal of Business and Management. 123-134. 